\title{
SNJEŽANA VESELICA-MAJHUT
}

iD https://orcid.org/0000-0002-1576-6098

Uniwersytet w Zagrzebiu

veselicamajhut@gmail.com

\section{TRUDNOŚCI ZWIĄZANE Z PRZEKŁADEM ELEMENTÓW KULTUROSPECYFICZNYCH W LITERATURZE KRYMINALNEJ: PRZYKŁAD CHORWACJI}

\section{Abstract}

\section{Challenges of Translating Cultural Embeddedness in Crime fiction: Croatia's Example}

The aim of the present study is to examine the specific features of translating crime fiction genre in Croatia in the 2000s. Frederic Jameson (qtd. in Rolls, Vuaille-Barcan, WestSooby 2016) foregrounded the notion of crime fiction's role as the new Realism due to the importance it places on historical and geographical specificity, and the social fabric of our daily lives. In line with this, an assumption could be made that the overvaluation of place in crime fiction may present a particular challenge in translation, not only in terms of translation strategies chosen by translators, but also in terms of preferable marketing strategies pursued by publishers and editors and the correspondence between them. The focus of this study is on the patterns of handling source-culture embeddedness, typical of this genre, in translation. The study examines how diverse agents (editors, translators and language revisers) involved in the production of translations of this genre interact and how their interaction influences the decisions on handling the genre's embeddedness in a particular, source-culture, reality. As crime fiction novels are a highly popular translated genre in Croatia, crime fiction novels make a substantial portion of the production of the publishing sector. For the purposes of this study I have selected a number of crime fiction novels by several frequently translated authors (P. D. James, Ruth Rendell, Michael Connelly) that have been published by Croatian publishers of diverse profiles, ranging from well-established publishers with long presence on the market to start-ups with a relatively short market life. The data analyzed include interviews with the agents 
involved (translators, editors and language revisers), peritext of these editions and analysis of selected textual segments.

Keywords: crime fiction. CSI in translation, genre translation in Croatia

Słowa kluczowe: literatura kryminalna, przekład CSI, przekład gatunkowy w Chorwacji

\section{Wstęp}

Choć związki pomiędzy literaturą kryminalną a przekładem zawsze były bliskie, zainteresowanie przekładoznawców tym gatunkiem ma stosunkowo krótką historię. Obecnie światowa popularność literatury kryminalnej rośnie (por. Worthington 2011; Franks 2011; 2014; Rolls 2015; Nilsson, Damrosch, D’haen 2017), dzięki czemu stała się ona ,przemysłem wartym miliony dolarów, [produkującym] historie rozpowszechniane za pośrednictwem rozmaitych mediów, między innymi w formie książek oraz ich adaptacji telewizyjnych i filmowych, znajdujących odbiorców na całym świecie" (Nilsson, Damrosch, D’haen 2017: 1). Opisując zjawisko, jakim jest literatura kryminalna, Heather Worthington (2011: ix) twierdzi:

Na początku XXI wieku literatura kryminalna przewyższa popularnością wszystkie inne gatunki, nawet poczytne romanse. Księgarnie i biblioteki sprzedają i wypożyczają więcej kryminałów niż jakichkolwiek innych książek. $\mathrm{Na}$ listach bestsellerów w gazetach i czasopismach nieodmiennie pojawiają się kryminały, w księgarniach znajdziemy osobne działy im poświęcone, a w telewizji i kinie można natrafić na wiele rozmaitych interpretacji w obrębie tego gatunku (wyróżnienie S.V.M.).

Nie trzeba przypominać, że popularność literatury kryminalnej na świecie nie rosłaby tak gwałtownie, gdyby nie przekład. Bliskie związki przekładu i literatury kryminalnej przejawiają się nie tylko poprzez globalne rozprzestrzenianie się kryminałów ${ }^{1}$ dzięki przekładowi - przekład od początku od-

${ }^{1}$ Choć wykracza to poza zakres niniejszego artykułu, warto podkreślić, że równolegle z rozprzestrzenianiem się literatury kryminalnej jako gatunku różne jej „lokalne” czy „narodowe" odmiany zyskują popularność na skalę światową. Zauważając to zjawisko, Andreas Hedberg (2017) wskazuje, że niedawna globalizacja literatury kryminalnej, widoczna zarówno w zakresie jej rozprzestrzeniania się w sensie geograficznym, jak i w rosnącej gamie poruszanych w niej tematów, może wynikać ze specyficznego połączenia cech uniwersalnych i specyficznych, promowanego $\mathrm{w}$ obrębie tego gatunku. Po przeniesieniu na nowy grunt 
grywał istotną rolę w formowaniu się gatunku, jakim jest kryminał. Dlatego też Alistair Rolls, Marie-Laure Vuaille-Barcan i John West-Sooby (2016: 136) podkreślają „formacyjną rolę przekładu dla literatury kryminalnej”, przytaczając jako przykład Zabójstwo przy Rue Morgue Edgara Allana Poego. Wpływu przekładu na rozwój kryminału jako gatunku nie można sprowadzić wyłącznie do faktu, iż pierwsze dzieła literatury kryminalnej narodziły się w obszarze kultury anglo-amerykańskiej², a następnie stały się dostępne dla czytelników z innych obszarów językowych za pośrednictwem przekładów, które z kolei zainspirowały kiełkujące rodzime tradycje. Przekładając opowiadania kryminalne Poego, Charles Baudelaire stworzył „nową poetykę współczesności” (Rolls, Vuaille-Barcana, West-Sooby 2016: 137):

W naszym odczuciu warto w tym przypadku mówić o ogniwie przekładu [a nexus of translation], czy raczej o „strefie kontaktu”, używając terminologii zaproponowanej przez Stephena Greenblatta w jego manifeście mobilności kulturowej (2009)3 , w której dwa gatunki (,amerykańska” proza kryminalna i ,paryska” proza poetycka) wspólnie zyskują na znaczeniu dzięki międzykulturowej wymianie (wyróżnienie S.V.M.).

Jak wskazuje Karen Seago (2014), dominujący w badaniach nad przekładem nacisk na kanon literatury pięknej sprawia, że przekładoznawcy jedynie sporadycznie poświęcają uwagę gatunkom popularnym, w tym literaturze kryminalnej. Wciąż nie powstała ,,ani jedna monografia poświęcona przekładom literatury kryminalnej i dysponujemy jedynie kilkoma artykułami, które w większości traktują kryminały jako korpus, lecz nie odnoszą się do problemów charakterystycznych dla przekładu literatury należącej do tego gatunku" (2014: 3). Zdaniem Seago warto poświęcić więcej uwagi specyficznym wyzwaniom, jakie literatura kryminalna może stawiać przed tłumaczem. Dla przykładu, badaczka postuluje zbadanie, „w jakim zakresie i w jaki sposób konwencje i ograniczenia wynikające z przynależności

kulturowy standardowa forma tekstu kryminalnego pozostaje niezmieniona, jednak narracja staje się przesycona elementami specyficznymi, pełnymi „lokalnego” kolorytu w zakresie postaci i miejsca akcji. „Glokalna” natura literatury kryminalnej znajduje odzwierciedlenie w splocie dość stałych motywów, które jednak oddają lokalne realia, co składa się na efekt łączący w sobie element wyjątkowości i przyjemnie swojską atmosferę.

${ }^{2}$ Nikt dotąd nie próbował podważyć tego ogólnie przyjętego założenia. Zob. Nilsson, Damrosch, D'haen (2017).

3 Polski przekład fragmentu książki: Mobilność kulturowa. Wprowadzenie, przeł. M. Borowski, M. Sugiera, „Didaskalia” 2011, 106, s. $42-47$ (przyp. tłum.). 
do tego gatunku, a także charakterystyczna dlań struktura i tematyka oraz specyficzne cechy formalne i retoryczne przekładają się na kształtowanie strategii thumaczeniowych" (2014: 4).

Jedną z cech charakterystycznych dla kryminału jako gatunku wskazał Fredric Jameson w wykładzie plenarnym Mówienie prawdy: Literatura kryminalna a alegoria narodowa, wygłoszonym na konferencji na Uniwersytecie Wollongong w 2012 roku. Jameson (cyt. w: Rolls, Vuaille-Barcan, West-Sooby 2016) określa literaturę kryminalną mianem „nowego realizmu”, podkreślając takie istotne aspekty kryminału, jak nacisk na odwzorowanie realiów historycznych, geograficznych i społecznych.

W niniejszym artykule przyjmuję nieodłączny dla literatury kryminalnej „nowy realizm” jako jedną z najciekawszych cech tego gatunku, objawiających się w chwili, gdy fabuły te podlegają przekładowi i wynikającemu zeń przeniesieniu do innych obszarów kulturowo-językowych. Założeniem artykułu jest wpisanie się w linię badań postulowaną przez Seago (2014), czyli zbadanie, w jaki sposób cechy beletrystyki kryminalnej wskazane przez Jamesona jako charakterystyczne dla „nowego realizmu” - prawdopodobność realiów oraz zakotwiczenie w konkretnym miejscu i czasie - są traktowane w najnowszych przekładach kryminałów na chorwacki. Ściślej mówiąc, zależy mi na zbadaniu, jakim ograniczeniom podlegają decyzje tłumaczy w zakresie oddania elementów tekstów źródłowych, które jednoznacznie zakorzeniają te teksty w kulturze źródłowej, ze względu na konwencję gatunkową oraz wyobrażenia redaktorów i wydawców na temat oczekiwań czytelników.

\section{Metodologia i korpus}

\subsection{Metodologia}

Zbiór pytań badawczych, stanowiących punkt wyjścia do niniejszych rozważań, obejmuje następujące kwestie: 1) Jak tłumacze przekładają obecne w tekście źródłowym elementy zakorzenienia w kulturze źródłowej? 2) W jakim stopniu wybory thumaczy uwarunkowane są ograniczeniami typowymi dla tego gatunku literackiego? 3) Jak pozostale podmioty zaangażowane w przygotowanie przekładu (tj. wydawcy i redaktorzy) wpływają na wybory tłumaczy? 4) W jaki sposób decyzje tłumaczy są kształtowane przez wyobrażenia wydawców i redaktorów na temat oczekiwań czytelników, 
które być może można zrekonstruować na podstawie analizy paratekstów tekstu docelowego?

Aby rozstrzygnąć wymienione powyżej kwestie, dokonałam analizy trzech zestawów danych. W pierwszej kolejności przeanalizowałam dane tekstowe (segmenty wybranych tekstów źródłowych i docelowych), zgodnie z paradygmatem opisowych badań przekładu (Toury 1995: 70-1014). Następnie zbadałam peryteksty tekstów docelowych, potraktowane jako dowód na „paratekstowe ujęcie” tych tekstów przez redaktorów, a także pulę wywiadów przeprowadzonych osobiście z tłumaczami i redaktorami zaangażowanymi w powstawanie chorwackich przekładów, aby wybadać ich podejście i sposób rozumowania, a następnie zestawić pozyskane w ten sposób dane z otrzymanymi w drodze analizy danych tekstowych.

Analiza tekstu miała na celu zidentyfikowanie preferowanych przez tłumaczy rozwiązań w przekładzie elementów tekstów źródłowych odnoszących się do konkretnych realiów geograficznych, społecznych i kulturowych charakterystycznych dla kultury źródłowej. Odniesienia zakorzeniające teksty źródłowe w konkretnej rzeczywistości geograficznej i społeczno-kulturowej można zbiorczo określić mianem CSI (culture-specific items) lub odniesień typowych dla danej kultury, konotujących ,różne aspekty życia codziennego, takie jak szkolnictwo, polityka, historia, sztuka, instytucje, systemy prawne, jednostki miar i wag, nazwy miejsc, potraw i napojów, sporty i narodowe rozrywki istniejące w różnych krajach i narodach świata" (Antonini 2004: 159). Wszystkie te elementy można potraktować jako sygnały zakorzenienia tekstów źródłowych w kulturze źródłowej. Przyjęło się stosować wobec nich różne określenia: ,świat kulturowy” (cultural world, Ivir 1987; Newmark 1988), „realia” (realia) (Florin 1993), „odniesienia kulturowe" (cultural references, Mailhac 1996; Olk 2001; Davies 2003; Antonini 2004), „CSI” (Aixelá 1996; Kwieciński 2001; Veselica-Majhut 2012) oraz „pozajęzykowe odniesienia kulturowe” (extralinguistic cultural references, Pedersen 2011). W niniejszym tekście stosuję termin CSI.

Jak wspomniano wcześniej, dane na temat preferowanych strategii w przekładzie CSI pozyskane dzięki analizie tekstów zostaną wzbogacone analizą paratekstów towarzyszących tekstom docelowym. Termin „paratekst” został ukuty przez Gérarda Genette’a, który zdefiniował paratekst

${ }^{4}$ Autorka artykułu odwołuje się do dwóch rozdziałów książki Gideona Toury’ego: rozdziału 3 pt. Constituting a Method for Descriptive Studies (polski przekład: Toury 2009) oraz rozdziału 4: The Coupled Pair of Replacing + Replaced Segments. (przyp. thum.). 
jako „liminalne chwyty i konwencje, zawarte w książce i istniejące poza nią, stanowiące część skomplikowanej mediacji pomiędzy książką, autorem, wydawcą i czytelnikiem: tytuły, przedmowy, epigrafy i teksty na okładce" (Genette 1997: xviii) $^{5}$. Parateksty, jako elementy mediujące pomiędzy książką a czytelnikami, dzielą się na periteksty i epiteksty (Genette 1997: xviii). W niniejszym artykule analizujemy okładki książek jako element peritekstu, umożliwiający rozpoznanie strategii warunkujących proces „relokalizacji” tekstu docelowego w kulturze źródłowej.

\subsection{Opis pary tekstów źródłowych i docelowych w korpusie}

Na potrzeby niniejszego relatywnie wąsko zakrojonego studium praktyk towarzyszących przekładowi kryminałów na chorwacki na początku XXI wieku wytypowałam losowo trzy powieści popularnych anglo-amerykańskich autorów kryminałów ${ }^{6}$, których książki wielokrotnie przekładano na chorwacki. Są to: The Private Patient P.D. James, The Girl Next Door Ruth Rendell oraz The Reversal Michaela Connelly'ego.

The Private Patient (PP) jest częścią serii o inspektorze Dalglieshu. W Wielkiej Brytanii książka została wydana przez Faber and Faber w 2008 roku. Wydanie chorwackie w przekładzie Tomislava Belanovicia ukazało się w 2010 roku pod tytułem Privatna pacijentica. Slučaj Adama Dalgleisha (PPtn) nakładem wydawnictwa Profil w ramach serii „Profil krimić". Wydawnictwo Profil powstało pod koniec lat 90. XX wieku jako jedna z niewielkich nowych oficyn wydawniczych. Od tego czasu jednak rosło w siłę i od wczesnych lat dwutysięcznych po dziś dzień należy do największych wydawnictw na chorwackim rynku książki. Oprócz wielu tytułów podręcznikowych, zapewniających stały dochód dzięki subsydiom rządowym, Profil wydaje kanoniczną literaturę piękną i powieści popularne ${ }^{7}$.

${ }^{5}$ W polskim przekładzie: ,tytuł, podtytuł, śródtytuł; przedmowy, posłowia, wstępy, uwagi od wydawcy etc.; noty na marginesie, u dołu strony, na końcu; epigrafy; ilustracje, wrzutka reklamowa; notka na obwolucie lub na opasce i wszystkie sygnały dodatkowe, pióra autora lub innych osób, tworzące otoczkę (zmienną) tekstu, niekiedy zaś komentarz oficjalny bądź półoficjalny" (Genette 2014: 9) (przyp. tłum.).

6 Jak wiadomo, literatura kryminalna dzieli się na wiele podgatunków. Jednak ponieważ pracuję na małym korpusie, a moim celem jest jedynie wstępne naświetlenie poruszanego problemu, nie biorę pod uwagę podziału na podgatunki.

7 Oto jak wydawnictwo Profil promuje się na swojej stronie internetowej: „Wydajemy beletrystykę i literaturę faktu od 2001 roku. Jesteśmy dumni z naszych pięknych wydań dzieł 
Seria „Profil krimić” ukazuje się od 2004 roku. Już samo użycie słowa krimić, kolokwialnego określenia kryminału, wskazuje intencje wydawcy, by przedstawić książki z serii jako dobrą rozrywkę.

Większa część akcji The Private Patient rozgrywa się w Cheverell Manor, prywatnej klinice w Dorset, prowadzonej przez sławnego chirurga plastycznego George'a Chandler-Powella. W powieści znajdziemy również sporo precyzyjnych odniesień do rozmaitych miejsc w Londynie. Oprócz odniesień do istniejących miejsc, powieść zawiera mnóstwo odwołań do konkretnych realiów, tworzących kanwę codziennego życia bohaterów.

The Girl Next Door (GND) autorstwa Ruth Rendell ukazała się po raz pierwszy w 2014 roku nakładem wydawnictwa Hutchinson. Chorwacki przekład Mirny Čubranić trafił na księgarniane półki dwa lata później pod tytułem Djevojka iz susjedstva (DS), nakładem wydawnictwa Mozaik Knjiga w serii „Mozaikova zabavna biblioteka”. Na swojej stronie internetowej wydawnictwo Mozaik Knjiga przedstawia się jako czołowy wydawca w Chorwacji, z listą pozycji obejmującą utalentowanych autorów rodzimych i zagranicznych, promujący klasykę oraz literaturę dziecięcą. Mozaik Knjiga podkreśla swoją rolę wydawnictwa ,dla całej rodziny”, oferującego lektury dla czytelników w każdym wieku, ,od najmłodszych po najstarszych". Według informacji zawartych w paratekście Djevojka iz susjedstva to 231. z kolei tytuł w serii „Mozaikova zabavna biblioteka”. Seria została zapoczątkowana w 2005 roku i do dziś obejmuje około 300 tytułów.

Fabuła powieści osnuta jest wokół zbrodni popełnionej siedemdziesiąt lat wcześniej, gdy pewien psychopata zamordował swoją żonę i jej kochanka, a następnie obciął im dłonie i ukrył je w puszce po ciastkach w tunelach pod położonym w sąsiedztwie Warlock House. Podczas prac budowlanych związanych z powstawaniem nowego osiedla makabryczne znalezisko zostaje odkryte i bohaterowie powieści, będący dziećmi w chwili popełnienia zbrodni, spotykają się ponownie w związku z prowadzonym śledztwem. Główny nacisk w powieści położony jest na dynamikę ich odnowionej znajomości oraz problemy związane z podeszłym wiekiem bohaterów raczej niż na samo śledztwo kryminalne. Autorka szczegółowo opisuje autentyczne

najlepszych pisarzy świata, od Margaret Atwood, przez Elenę Ferrante, Umberta Eco, Paula Austera, Marguerite Duras, Henry'ego Jamesa, Doris Lessing, Cormaca McCarthy'ego, Carlosa Fuentesa i Raymonda Carvera aż po międzynarodowe bestsellery, takie jak Kradljivica knjiga (wyd. pol. Złodziejka książek) i Žena vremenskog putnika (wyd. pol. Zaklęci w czasie). Wśród naszych autorów można znaleźć także poczytnych pisarzy współczesnych, takich jak Cecelia Ahern, Nora Roberts, John Le Carré czy Ian Rankin. 
miejsca, w których fikcyjni bohaterowie żyli bądź żyją, dodając mnóstwo detali dotyczących ich życia codziennego.

The Reversal (Rv) Michaela Connelly'ego to książka opublikowana w 2010 roku w Stanach Zjednoczonych, należąca do serii powieści o Mickeyu Hallerze. Chorwackie wydanie ukazało się w 2013 roku nakładem Lumen Izdavaštvo (wydawnictwa Lumen) pod tytułem Preokret (Pr), w przekładzie Brunona Šteficia. Lumen Izdavaštvo powstało w 2011 jako specjalizujący się w literaturze popularnej imprint najstarszego i największego w Chorwacji wydawnictwa o profilu akademickim, Školska Knjiga.

Fabuła książki Connelly’ego osnuta jest wokół ponownego procesu człowieka skazanego za brutalne morderstwo dziecka, gdy nowe dowody na podstawie śladów DNA świadczą o jego niewinności. Mickey Haller, adwokat z Los Angeles, zgadza się wystąpić w tej sprawie jako oskarżyciel z ramienia miasta Los Angeles, pod warunkiem, że sam wybierze śledczego, którym ma zostać detektyw Harry Bosch, przyrodni brat Hallera. Akcja rozgrywa się w okolicach Los Angeles i w książce pojawia się mnogość odniesień do popularnych miejsc w tym rejonie, między innymi do słynnej restauracji „,The Water Grill', które pełnią ważną funkcję w kreowaniu świata przedstawionego.

\subsection{CSI i możliwości ich oddania w tekstach docelowych}

Ponieważ przekładalność CSI należy do najszerzej omawianych zagadnień w badaniach nad przekładem - do tego stopnia, że zyskały sobie miano „punktu kryzysowego w przekładzie” (Pedersen 2007: 19) - istnieje wiele opracowań naukowych na ten temat ${ }^{8}$.

Konfrontując się z koniecznością przełożenia CSI, tłumacz ma do dyspozycji gamę dostępnych rozwiązań. Jak dowodzi Javier Franco Aixelá (1996: 65-71), na ostateczną decyzję tłumacza, jak oddać konkretny przypadek CSI, ma wpływ cały szereg czynników: parametr ponadtekstowy (poziom preskryptywizmu językowego, typ i oczekiwania potencjalnych czytelników, charakter i cele inicjatorów przekładu), parametr tekstowy (zależny od rodzaju CSI) oraz parametr wewnątrztekstowy. Ponieważ interesuje mnie przede

${ }^{8} \mathrm{Z}$ uwagi na ograniczone miejsce, nie zawieram tu przeglądu dostępnej literatury naukowej poświęconej temu zjawisku, odsyłając czytelników do ważniejszych prac na ten temat: Ivir (1987); Hervey, Higgins (1992); Aixelá, (1996), Mailhac (1996), Newmark (1998), Kwieciński, (2001), Davies (2003), Pedersen (2011). 
wszystkim związek pomiędzy konwencją gatunkową i wyborami tłumaczy, skupiam się na kategorii określonej przez Aixelę jako parametr ponadtekstowy.

Na potrzeby przedstawionej poniżej analizy zmodyfikowałam przygotowaną wcześniej taksonomię metod odwzorowania CSI w przekładzie. Bardziej rozwinięta wersja taksonomii została użyta w szerzej zakrojonym badaniu odwzorowania CSI w przekładach powieści Agathy Christie na chorwacki (Veselica-Majhut 2012). Okroiłam i uprościłam tę taksonomię, kierując się użytecznym komentarzem Henrika Gottlieba (2009: 32) dotyczącym najważniejszych elementów, o jakich warto pamiętać przy ustalaniu kategorii mających naświetlić pewne prawidłowości w przekładach. Według Gottlieba należy zadbać przede wszystkim o to, by przyjęte kategorie obejmowały całość wyników badania, a także by odzwierciedlały one istotne różnice w wynikach. Wreszcie istotne jest, by liczba kategorii była dostosowana do rozmiarów korpusu.

Ogólnie mówiąc, wybór określonego rozwiązania przekładowego w odniesieniu do danego przypadka CSI będzie miał przełożenie na poziom tekstowy tekstu docelowego oraz przyniesie jeden z następujących efektów: przyczyni się do zachowania zakorzenienia tekstu w kulturze źródłowej, zneutralizuje znaczenia o specyfice kulturowej w tekście docelowym lub zastąpi odniesienia typowe dla kultury źródłowej odniesieniami właściwymi dla kultury docelowej, przyczyniając się tym samym do asymilacji tekstu w nowym kontekście kulturowym.

Zanim przejdziemy do analizy sposobu, w jaki CSI umiejscawiające tekst źródłowy w konkretnym kontekście geograficznym i społeczno-kulturowym są traktowane w przekładzie, chcę przedstawić pokrótce taksonomię rozwiązań przekładowych użytą w niniejszym badaniu. Wszystkie rozwiązania stosowane przez tłumaczy zostały podzielone na dwie kategorie: strategie proste i strategie złożone. Strategie złożone wynikają z połączenia dwóch różnych strategii prostych, zazwyczaj zachowania nazwy własnej i dodatków wewnątrztekstowych lub pozatekstowych (zob. „glossa wewnątrztekstowa” i ,glossa pozatekstowa”, Aixelá 1996). W tabeli 1 przedstawiam wszystkie typy rozwiązań przekładowych, poczynając od najbardziej egzotyzujących (zorientowanych na kulturę źródłową), poprzez strategie neutralizujące, po te najbardziej asymilujące (zorientowane na kulturę docelową). Towarzyszą im objaśnienia i przykłady zaczerpnięte $\mathrm{z}$ analizowanych powieści. 


\begin{tabular}{|c|c|c|c|c|}
\hline 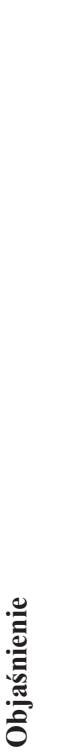 & 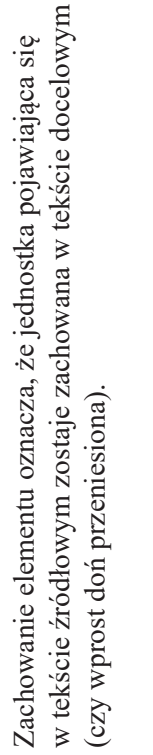 & 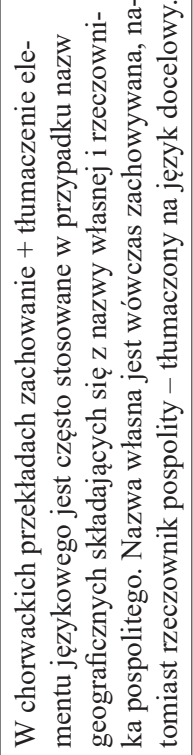 & 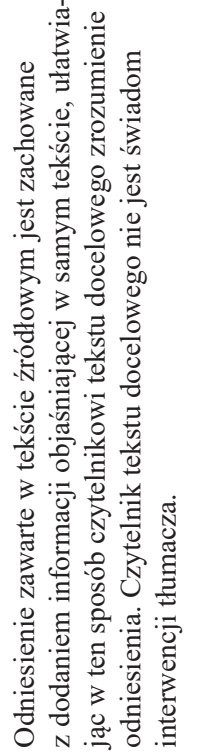 & 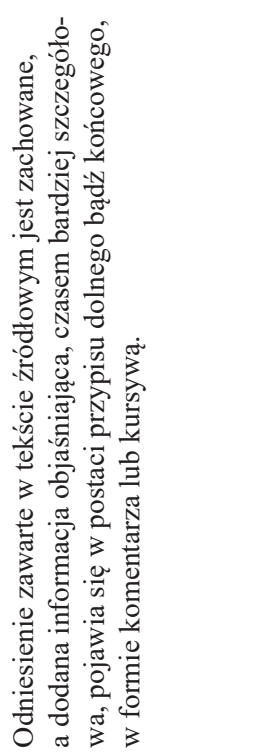 \\
\hline$\sqrt{2}$ & 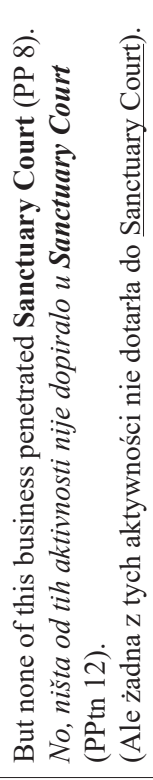 & 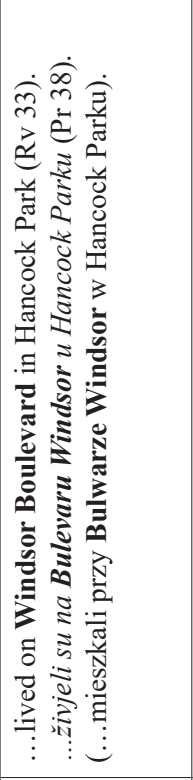 & 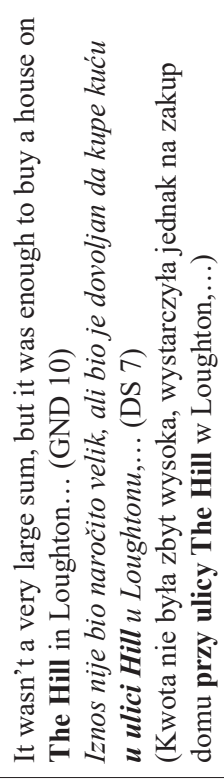 & 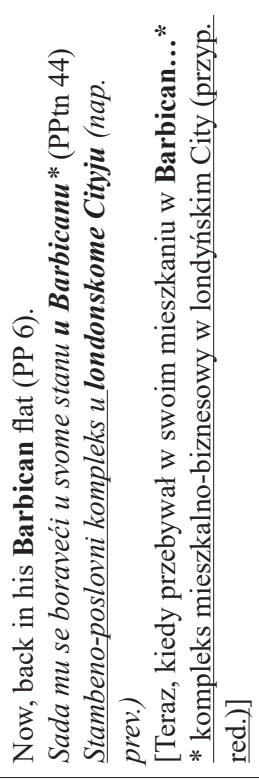 \\
\hline 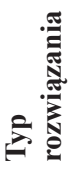 & 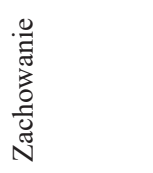 & 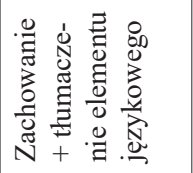 & 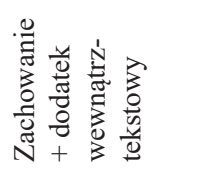 & 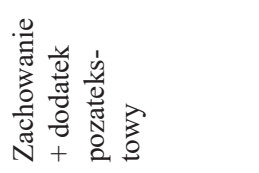 \\
\hline
\end{tabular}




\begin{tabular}{|c|c|c|c|}
\hline 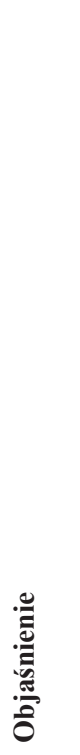 & 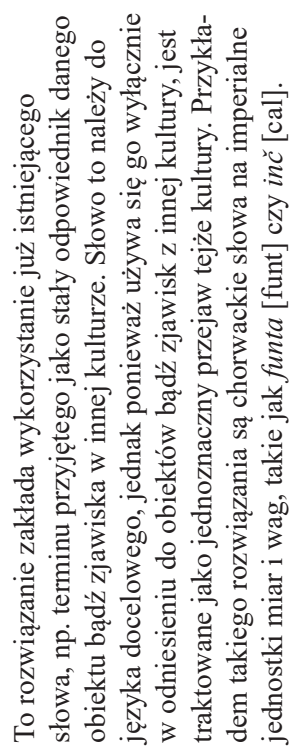 & 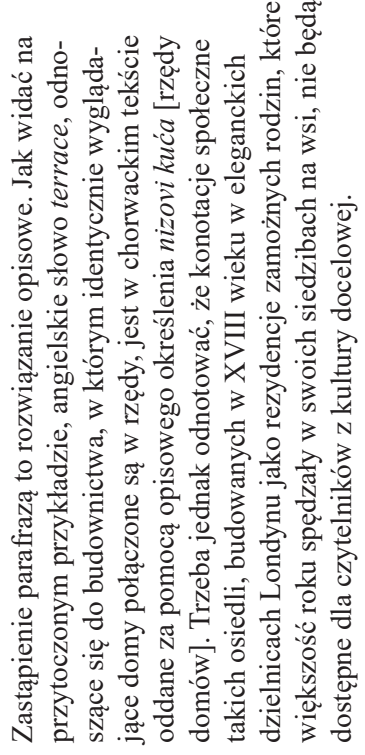 & 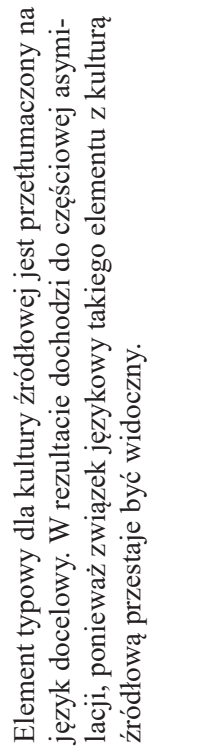 \\
\hline$\sqrt{\infty}$ & 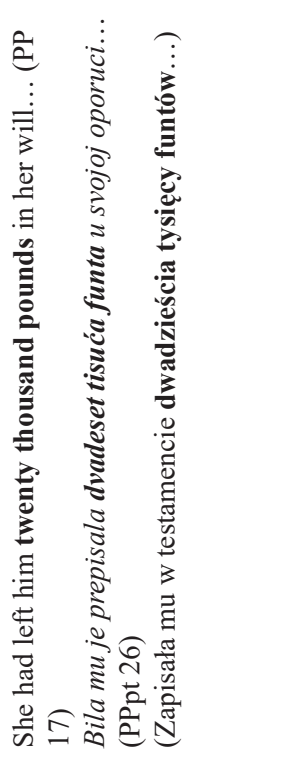 & 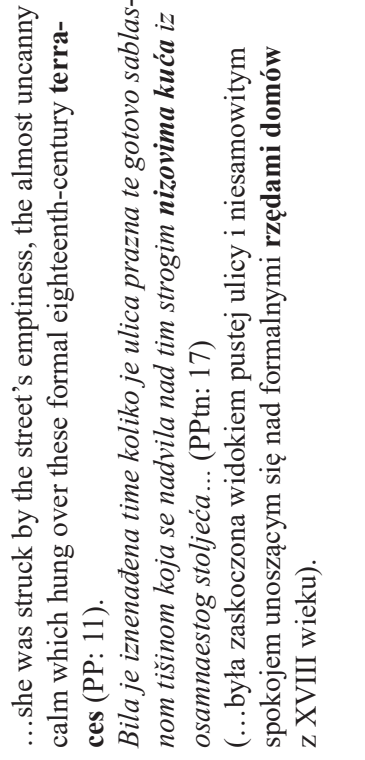 & 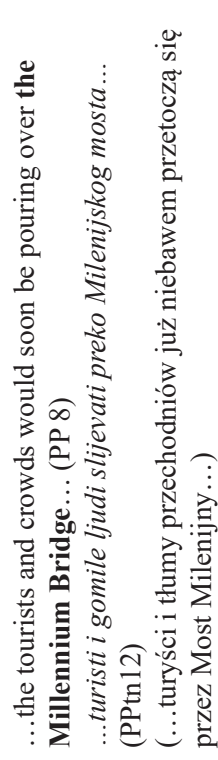 \\
\hline 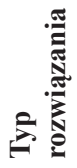 & 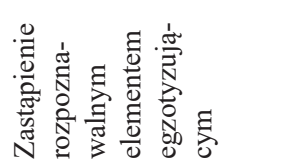 & 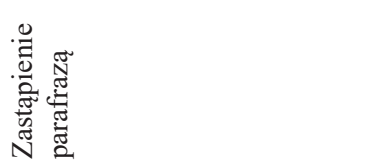 & 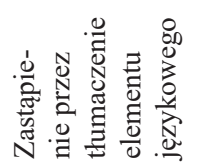 \\
\hline
\end{tabular}




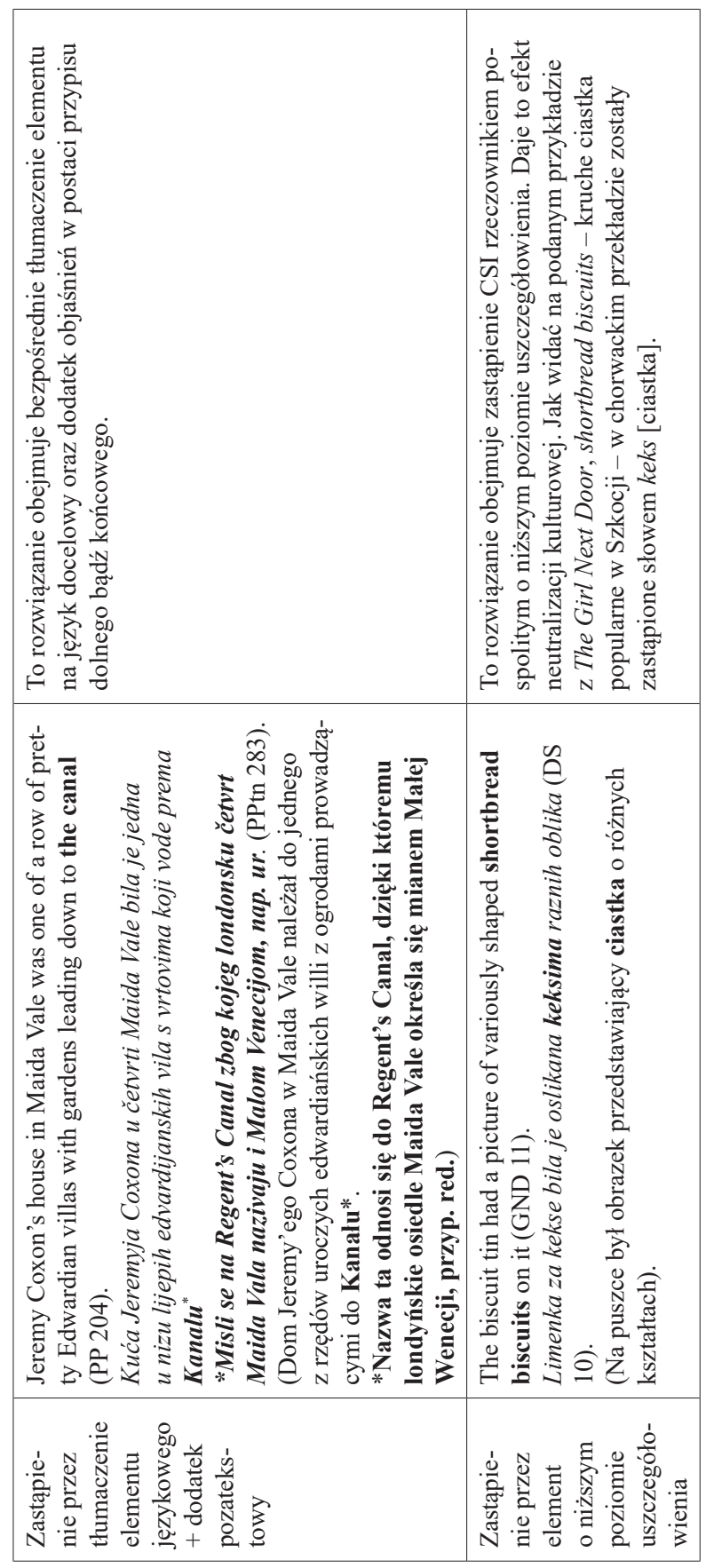




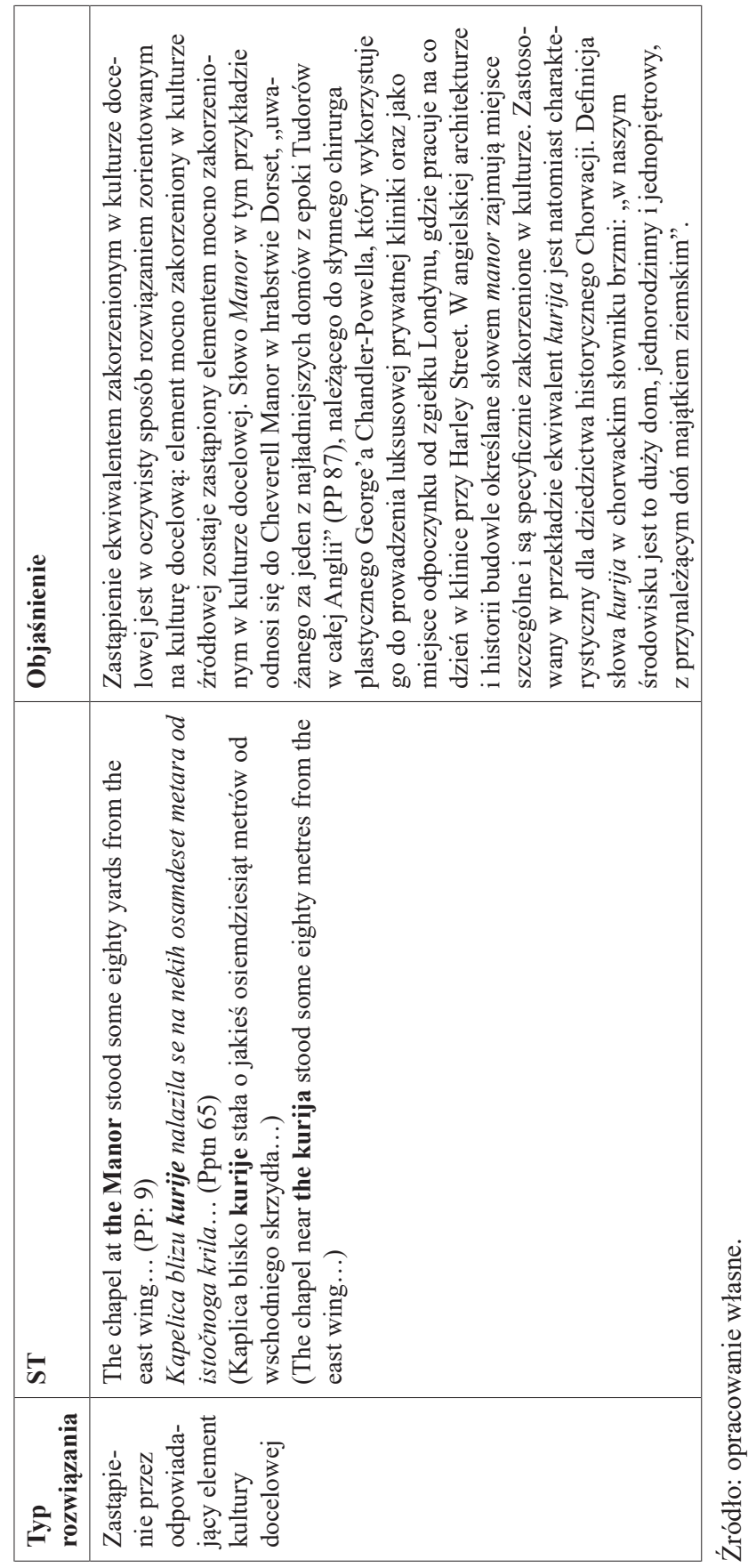


Wszystkie rozwiązania przekładowe przedstawione w tabeli 1 można sklasyfikować w odniesieniu do ich przełożenia na nacechowanie kulturowe tekstu docelowego: egzotyzację, neutralizację, asymilację bądź edukację. Do analizy wykorzystałam stworzony uprzednio model orientacji na poziomie tekstowym (Veselica-Majhut 2012). Ilekroć thumacze decydują się na zastosowanie jednej ze strategii złożonych, polegających na połączeniu jednej ze strategii prostych z elementem dodatkowym, ich wybór ma przełożenie na wartość informacyjną bądź edukacyjną tekstu docelowego. Model ilustrujący skutki wybranych rozwiązań na orientację tekstu docelowego można prześledzić na wykresie 1. Opis wykresu znajduje się poniżej.

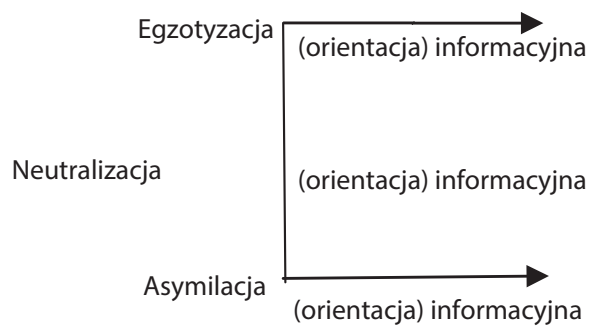

Wykres 1. Model orientacji na poziomie tekstowym

Źródło: opracowanie własne.

W odróżnieniu od modeli linearnych opartych na modelu Sandora Herveya i Iana Higginsa (1992), proponowany przeze mnie model dzieli możliwe strategie według dwóch kryteriów: obecności elementów nacechowanych kulturowo w tekście docelowym i poziomu adekwatnej informacji na temat elementów kultury źródłowej obecnych w tekście docelowym.

Rozwiązania przyczyniające się do zachowania/neutralizacji elementów właściwych dla kultury źródłowej bądź ich zastąpienie elementami typowymi dla kultury docelowej umieszczone zostały wzdłuż osi pionowej, z zachowaniem po stronie egzotyzacji i zastąpieniem ekwiwalentem zaczerpniętym z kultury docelowej po stronie asymilacji. Rozwiązania eliminujące elementy nacechowane kulturowo należą do grupy neutralizujących, wizualnie oddzielonych od osi pionowej. Osie poziome wskazują na poziom informacyjności każdego z rozwiązań. Zdając sobie sprawę z tego, że poziom informacji na temat elementów nacechowanych kulturowo nie jest automatycznie zintegrowany z żadną z orientacji odzwierciedlających 
obecność odniesień kulturowych, wprowadziłam do modelu taką orientację, aby odzwierciedlić różnice w poziomie wartości informacyjnej różnych typów rozwiązań. Podczas gdy strategie takie jak zachowanie oraz zachowanie + dodatek pozatekstowy przyczyniają się do podtrzymania zakorzenienia tekstu docelowego w kulturze źródłowej, różnica pomiędzy nimi polega na ilości informacji przekazywanych czytelnikowi tekstu docelowego. Widać to dobrze na poniższych przykładach:

Przykład 1:

Now as he got out of the train and made his way along the canal to the bridge and Maida Vale... (GND 49)

Sad kad je izišao iz vlaka i hodao uz kanal do mosta i Maida Vale... (DS 75) (Teraz, kiedy wysiadł z pociągu i szedł wzdłuż kanału w stronę mostu i Maida Vale...)

Przykład 2:

The journey from the City shouldn't take three-quarters of an hour but the London traffic was unpredictable... (PP 7)

Put iz Cityja* ne bi trebao potrajati četrdeset pet minuta, no londonski je promet nepredvidiv.

* Povijesna jezgra i financijsko središte Londona (nap. ur.) (PPtn: 11) [Podróż z City* nie powinna zająć więcej niż czterdzieści pięć minut, jednak londyńskie korki były nieprzewidywalne.

* Historyczne i finansowe centrum Londynu (przyp. red.)]

Jak pokazuje porównanie przykładów 1. i 2., w obu przypadkach odniesienia do konkretnych miejsc w Londynie - Maida Vale i City - zostają zachowane w przekładzie. Różnica polega na tym, że w przykładzie 2. czytelnik tekstu docelowego otrzymuje dodatkową informację kulturową na temat miejsca akcji.

Strategie asymilujące mają na celu ,przeniesienie” elementów tekstu źródłowego do kultury docelowej. Dobrym przykładem takiej strategii jest analizowana wcześniej para fragmentów z powieści The Private Patient, której akcja rozgrywa się w Cheverell Manor w hrabstwie Dorset, „uważanym za jeden z najładniejszych domów z epoki Tudorów w całej Anglii” (PPtn 87). Wskutek decyzji tłumacza, jak widać w tabeli 1, nazwa Cheverell Manor 
została oddana jako kurija Cheverell. Angielskie wyobrażenie tego, czym jest manor, wraz z towarzyszącymi mu konotacjami kulturowymi, zostało zastąpione przez słowo kurija, a więc chorwacki koncept niosący ładunek konkretnych konotacji w kulturze docelowej. Jak pisze Jeremy Musson (1999: 7), domostwa określane jako manor odegrały istotną rolę w ,tradycji angielskiego romantyzmu”, a ponadto „cieszyły się kultowym statusem pod koniec XIX i na początku XX wieku” (Musson 1999: 7). Tymczasem pojęcie kurija wiąże się ściśle z historią kontynentalnej Europy. Ekwiwalent przyjęty przez tłumacza do pewnego stopnia semantycznie pokrywa się ze znaczeniem słowa manor, jednak eliminuje wszystkie społeczno-kulturowe konotacje, jakie termin ten niesie z sobą dla czytelników tekstu źródłowego. Trzeba jednak zaznaczyć, że zastąpienie przez odpowiadający element kultury docelowej jest najrzadziej używaną przez tłumaczy strategią w moim korpusie.

Zastąpienie przez tłumaczenie językowe zakłada językowe tłumaczenie odniesienia. W tabeli 1 strategię tę ilustruje przykład z Millennium Bridge, oddanym jako Milenijski most. Do alternatywnych rozwiązań należałoby zachowanie nazwy Millennium Bridge, co dałoby bardziej egzotyzujący efekt, bądź zastąpienie nazwy własnej rzeczownikiem pospolitym „most”, co z kolei zaskutkowałoby neutralizacją.

\section{Wnioski}

\subsection{Wnioski z analizy tekstowej}

Systematyczna analiza wybranych rozdziałów przekładów Djevojka iz susjedstva (rozdziały 1 i 2), Privatni pacijent (rozdziały 3 i 6) oraz Preokret (rozdziały 11 i 13) przyniosła następujące wnioski. Zidentyfikowałam 40 CSI w rozdziałach 1 i 2 powieści The Girl Next Door, z których większość (26) była odniesieniami geograficznymi. Wszystkie oddano w tekstach docelowych przy użyciu strategii zachowania, co wyraźnie wskazuje na troskę o oddanie oryginalnego miejsca akcji. Jedynie w dwóch przypadkach zachowanie połączono z dodatkiem wewnątrztekstowym, na przykład: „He’d had his hip done and he was just coming back from St Margaret's" (GND 18) jako „Operirao je kuk i baš se vraćao iz bolnice St Margaret's” (DS 21). Prowadzi to do wniosku, że dominująca strategia w tekście wskazuje na egzotyzację - innymi słowy, makrostrategia tłumacza polega na zachowaniu 
„atmosfery” tekstu źródłowego i odwzorowaniu świata przedstawionego zgodnie z tamtejszymi realiami. Wydaje się to świadomie przyjętą strategią, jako że w wielu wypadkach rozwiązania neutralizujące sprawdziłyby się równie dobrze i nie nastręczyłyby czytelnikowi najmniejszych trudności przy śledzeniu fabuły. Na przykład powyższe odniesienie do St Margaret's można by z łatwością oddać po prostu jako „szpital”.

W rozdziałach 3 i 6 powieści Privatna pacijentica zidentyfikowałam 44 CSI. Duża część z nich (21) odnosiła się do nazw geograficznych, z których wszystkie zostały zachowane w przekładzie. Podobnie jak w książce Djevojka iz susjedstva, chorwackie wydanie zachowuje oryginalne miejsca akcji, a tekst docelowy przesiąknięty jest specyficzną atmosferą zakorzenienia w kulturze źródłowej.

W rozdziałach 11 i 13 powieści Preokret znalazłam 19 CSI, z których jedynie 5 stanowiło odniesienia do miejsc. Wszystkie zostały zachowane bądź oddane za pomocą zachowania + tłumaczenia elementu językowego.

Rzadkie stosowanie dodatków wewnątrztekstowych i pozatekstowych w omawianych przekładach wskazuje na oszczędne stosowanie rozwiązań informacyjnych, których celem jest przekazanie czytelnikowi informacji na temat denotatywnych bądź konotatywnych znaczeń odniesień zakorzenionych w kulturze źródłowej. We wszystkich trzech omawianych tekstach docelowych dodatki pozatekstowe występowały w formie przypisów dolnych.

Co się tyczy używania przypisów w przekładach beletrystyki, nie istnieją ogólnie przyjęte zasady, lecz każda kultura wypracowała w tej kwestii własne tradycje. Dla przykładu Clifford E. Landers (2001: 93) odradza używanie przypisów w przekładach prozy fabularnej, argumentując, iż przypisy zaburzają „,efekt mimetyczny [...]. Przypisy dolne wybijają z rytmu lektury, każą wzrokowi czytelnika oddalić się na chwilę od tekstu książki i śledzić informacje, które - choć przydatne - zaburzają chwilową wiarę w prawdziwość świata przedstawionego [is still a disrupter of 'the willing suspension of disbelief ']". Oszczędność w stosowaniu przypisów wydaje się powiązana z przystępnością lektury jako jedną z kluczowych cech gatunkowych kryminału. Zdaniem krytyków powieści kryminalne ,,przytacza się jako modelowy przykład tekstów czytanych bez wysiłku" (Pyrhönen 2010: 54).

Podsumowując, analiza tekstowa wykazała, iż tłumacze z jednej strony skłaniają się ku strategiom egzotyzującym, z drugiej zaś unikają strategii informacyjnych, co może być pochodną cech gatunkowych kryminału i oczekiwań czytelników. 
Mimo iż pracowałam na niewielkim korpusie, poczynione spostrzeżenia nasuwają konkretne pytania dotyczące odwzorowania realiów społeczno-kulturowych w przekładach kryminałów. Nacisk na zachowanie CSI oznacza, że teksty docelowe są nieodmiennie mocno zanurzone w kulturze źródłowej. Jednak znaczna część CSI w moim korpusie to nie nazwy geograficzne, lecz odniesienia do miejsc reprezentujących rozmaite instytucje i niosących ważne konotacje społeczno-kulturowe właściwe dla kultury źródłowej, z łatwością odczytywane przez odbiorców tekstu źródłowego. Oto kilka przykładów:

Przykład 3:

He never stayed longer than a week before flying to Rome where he stayed in the same pensione outside the city he had first visited when at Oxford... (PP 30)

Nije se nikada ondje zadržavao dulje od tjedan dana nakon čega bi otputovao u Rim, gdje bi odsjeo u pansionu u blizini grada koji je prvi put posjetio tijekom studija na Oxfordu... (PPtn 44)

(Nigdy nie zostawał dłużej niż tydzień, a potem ruszał do Rzymu, gdzie zatrzymywał się w hoteliku niedaleko miasta, które po raz pierwszy odwiedził podczas studiów w Oxfordzie)

Przykład 3 pochodzi z fragmentu, w którym bohater książki, George Chandler-Powell, człowiek „u szczytu zawodowej sławy”, wspomina, jak dawniej spędzał ferie świąteczne. Fraza when at Oxford została oddana z zachowaniem nazwy Oxford z dodatkiem wewnątrztekstowym ,podczas studiów w...", który ma na celu uświadomić czytelnikowi, że nie chodzi o miejsce, w którym bohater mieszkał w przeszłości, lecz o uczelnię, do której nazwa ta metonimicznie się odnosi. Natomiast to, co studia w Oxfordzie mówią o pozycji społecznej bohatera, jest już pozostawione do rozpoznania czytelnikowi na podstawie wiedzy kulturowej, którą ten może, lecz nie musi posiadać. Widać to dobrze na kolejnym przykładzie:

Przykład 4:

I used to imagine them, edging their way with brains and talent into the Boars Hill academic dinner parties... (PP 31) 
Zamišljao bi ih da se zahvaljujući svojoj darovitosti i pameti uspijevaju ugurati na akademske večere u Boars Hillu... (PPtn 46)

(Wyobrażałem sobie, jak dzięki talentowi i inteligencji udało im się załapać na kolacje akademików w Boars Hill...)

Przykład 4 pochodzi z fragmentu książki, w którym Herbert Chandler-Powell, dziadek George'a, opowiada wnukowi o czasach, gdy sam studiował w Oxfordzie dzięki otrzymanemu stypendium, jednak nigdy nie czuł się tam swobodnie. Zazdrościł zdolnym i ambitnym kolegom, zabiegającym o to, by stać się częścią akademickiej społeczności. Jak widać w przykładzie 4, czytelnik nie otrzymuje żadnych wskazówek w postaci dodatkowych informacji o tym, czym jest Boars Hill, i musi domyślić się z kotekstu, że chodzi o miejsce, do którego mogli aspirować młodzi ludzie o niewystarczająco arystokratycznym pochodzeniu. Istotne społecznie konotacje odniesienia do Boars Hill dostępne dla czytelników tekstu źródłowego można podsumować następująco: „Społeczność z Boars Hill stanowiła «przekonaną o swojej wartości elitę intelektualną», miejsce to kojarzono z dużą populacją uczonych, pisarzy i artystów, świadomych swojej roli jako twórców kultury i elity angielskiego społeczeństwa" (Scott-Brown 2017: 156).

Przytoczę jeszcze jeden przykład, ilustrujący przepastną różnicę w wiedzy kulturowej pomiędzy czytelnikami tekstu źródłowego i docelowego, wynikającą z oszczędnego stosowania strategii informacyjnych. Główni bohaterowie powieści Djevojka iz susjedstva, Alan i Rosemary Norris, tradycyjna para w starszym wieku, przeżywszy, według słów Alana, „nudne życie”, znajduje w gazecie wiadomość o makabrycznym odkryciu puszki zawierającej odcięte dłonie. Poniższy fragment zawiera CSI o szczególnym znaczeniu dla nakreślenia portretu współczesnego brytyjskiego społeczeństwa:

Przykład 5:

The Daily Telegraph spread out on the dining table, Alan was reading about a discovery made by three Polish builders under a house called Warlock, on The Hill...

'What a name,' said Rosemary, reading it over his shoulder. 'Zbigniew. Is that how you pronounce it?' (GND 17) 
Raširivši Daily Telegraph na blagovaonički stol, Alan je čitao o onome što su tri građevinska radnika Poljaka pronašla ispod kuće pod imenom Warlock na Hillu...

- Kakvo ime - rekla je Rosemary čitajući preko njegova ramena. - Zbigniew. Izgovara li se tako? (DS 19)

(Rozpostarłszy The Daily Telegraph na stole w jadalni, Alan przeczytał o odkryciu poczynionym przez trzech budowlańców z Polski pod domem o nazwie Warlock na Hill...

- Co za imię - stwierdziła Rosemary, zaglądając mu przez ramię. - Zbigniew. Czy tak się to czyta?]

„The Daily Telegraph” to gazeta kupowana przez konserwatywnych czytelników. Wybór tego właśnie tytułu nie tylko wskazuje na polityczne sympatie bohaterów, lecz także podpowiada ich przynależność klasową. Według statystyk National Readership Surveys za rok 1993, „The Daily Telegraph" cieszył się szczególną popularnością wśród osób należących do kategorii społecznych A, B i C (wyższa klasa średnia, klasa średnia i niższa klasa średnia) (zob. Westin 2002: 9). Fakt, że robotnik, który znalazł puszkę, jest Polakiem, a Rosemary nie wie, jak wymówić jego imię, stanowi aluzję do kolejnego aspektu życia we współczesnym Zjednoczonym Królestwie, które doświadczyło masowej imigracji z Europy Wschodniej po przystąpieniu państw tego regionu do UE.

Podsumowując, zaobserwowaliśmy różne tendencje w zakresie wyborów strategii przez tłumaczy: z jednej strony zauważalna jest tendencja do zachowywania w przekładzie większości CSI, co daje efekt zakorzenienia tekstu docelowego w środowisku właściwym dla kultury źródłowej. Z drugiej strony jednak należy odnotować, że imperialne jednostki miar, takie jak jard, mila czy cal, są konsekwentnie zastępowane odpowiednikami z kultury docelowej: metar, kilometar i centimetar. Tendencję tę można prawdopodobnie złożyć na karb dążenia do przystępności lektury tekstu docelowego, cechy typowej dla literatury kryminalnej - ta sama przyczyna, naszym zdaniem, stoi za oszczędnym stosowaniem strategii informacyjnych dodających objaśnienia do tekstu. 


\subsection{Wnioski z analizy perytekstu}

W poniższej części artykułu prezentujemy analizę okładek, czyli elementu peritekstu wyraźnie wskazującego na strategie wydawców i redaktorów towarzyszące wprowadzeniu książki na rynek i pozyskiwaniu czytelników. Żadne z omawianych wydań nie podkreśla faktu, że książka jest przekładem, ponieważ nazwisko tłumacza nie pojawia się na okładce, lecz na stronie tytułowej. Jest to zgodne z przyjętą w Chorwacji konwencją, a nazwisku thumacza towarzyszy fraza taka jak: Z engleskoga preveo Tomislav Belanović [z angielskiego przełożył Tomislav Belanović].

Najbardziej rzucającym się w oczy elementem wizualnym na pierwszej stronie okładki książki Privatna pacijentica jest nazwisko autorki tekstu źródłowego, P.D. James, wydrukowane dużą, pogrubioną czcionką. Tytuł książki umieszczony jest pod nazwiskiem autorki i zapisany mniejszym stopniem pisma. Ponad wyraźnie zaznaczonym nazwiskiem autorki widnieje slogan przedstawiający książkę jako „nową powieść pierwszej damy brytyjskiego kryminału" (wyróżnienie moje). U dołu okładki znajdziemy blurb z „The Telegraph” o treści: „Ekscytująca, jak zwykle...”. Widać, że strategia marketingowa wydawcy opiera się na założeniu, że chorwaccy czytelnicy są już zaznajomieni z reputacją autorki, a także z charakterystycznymi cechami gatunku: tajemnicą, ekscytacją, napięciem oraz dreszczykiem niepokoju wynikającym z rozbicia bezpiecznej wizji rzeczywistości w następstwie zbrodni. Ten ostatni element jest wzmocniony przez zdjęcie opuszczonego domostwa, kojarzącego się z tajemnicą i nierozwiązaną zagadką. Autorka P.D. James jest przedstawiona jako ,pierwsza dama”, czyli najwybitniejsza autorka, „brytyjskiego kryminału”. Prowadzi to do konkluzji, że działania marketingowe chorwackiego wydawcy opierają się na popularności autorki w kulturze źródłowej i jej przynależności do kanonu brytyjskiej literatury kryminalnej. Zgodnie z przyjętą konwencją, lewe skrzydełko okładki, uważane za ważny element peritekstu, który pomaga „sprzedać książkę”, zawiera krótki biogram P.D. James, podkreślający, że należy ona do „,najsłynniejszych i najbardziej podziwianych autorów kryminałów na świecie”. Na czwartej stronie okładki również najważniejszym elementem jest nazwisko autorki. Jak przyjęte jest w wydaniach kryminałów, pojawia się też krótki opis fabuły, ułożony w taki sposób, by zaintrygować czytelnika. Dłuższa część noty przedstawia książkę jako ,najnowszą powieść brytyjskiej autorki kryminałów P.D. James, która powraca do postaci Adama Dalgliesha, tym 
razem prowadzącego śledztwo w sprawie tajemniczej śmierci w klimacie typowym dla tej słynnej autorki klasycznych brytyjskich powieści kryminalnych: akcja rozgrywa się na południu Anglii, w hrabstwie Dorset, w Cheverell Manor, dawniej dużym majątku ziemskim, a dziś klinice chirurgii plastycznej prowadzonej przez sławnego lekarza George'a Chandler-Powella" (wyróżnienie moje). Nocie od wydawcy towarzyszą dwa blurby: „Prawdziwa przyjemność czytania” z ,The Observer” oraz „W budowaniu napięcia P.D. James nie ma sobie równych" $\mathrm{z}$, The Washington Post”. Podsumowując, jak pokazuje analiza werbalnych i wizualnych elementów okładki, strategia marketingowa wydawcy koncentruje się wokół renomy autorki oraz konwencjonalnych oczekiwań czytelników wobec powieści kryminalnej (jako lektury pełnej napięcia i dostarczającej rozrywki). Warto również podkreślić użycie sformułowań takich jak ,typowy klimat”, „klasyczna brytyjska powieść kryminalna” i ,pierwsza dama brytyjskiego kryminału", wskazujących, że atrakcyjność książki w dużym stopniu wynika z jej „typowego klimatu” i brytyjskości.

Podczas gdy w wypadku powieści P.D. James wydawca podkreśla brytyjskość książki, Djevojka iz susjedstva, wydana przez Mozaik Knjiga, reklamowana jest na pierwszej stronie okładki jako „wielki światowy hit”. Najbardziej wyrazistym elementem wizualnym jest tytuł książki, wydrukowany dużą, pogrubioną czcionką. Odwrotnie niż w przypadku powieści Privatna pacijentica, tutaj to nazwisko autorki pojawia się poniżej i mniejszym drukiem. Mimo to uwaga czytelnika zostaje skierowana na autorkę dzięki krótkiemu blurbowi, odznaczającemu się na okładce intensywnym niebieskim kolorem, autorstwa Iana Rankina: „Prawdopodobnie najpopularniejsza autorka kryminałów". Na lewym skrzydełku widnieje zdjęcie autorki oraz krótki biogram, podkreślający nagrody literackie, jakie otrzymała. Czytelnik znajdzie tu również listę wszystkich książek Rendell przetłumaczonych na chorwacki. Czwarta strona okładki ma za zadanie zaintrygować czytelnika, przedstawiając zarys fabuły. Prawe skrzydełko zawiera dwie rekomendacje: blurb Patrycji Cornwell i cytat z recenzji opublikowanej w „The Times Literary Supplement”. Cornwell nazywa Ruth Rendell „bez wątpienia najlepszą autorką kryminałów naszych czasów” i deklaruje, że pisarka „triumfuje dzięki swojemu wyjątkowemu, rozpoznawalnemu stylowi”. Podsumowując, w odróżnieniu od powieści Privatna pacijentica, wydawca książki Djevojka iz susjedstva stawia na międzynarodową popularność autorki, podkreślaną za pośrednictwem blurbów autorstwa poczytnych pisarzy kryminałów: Iana Rankina i Patricii Cornwell. 
Preokret Michaela Connelly'ego ma podobny paratekst jak Privatna pacijentica - najważniejszym elementem wizualnym na okładce jest nazwisko autora oraz blurb z „Los Angeles Times”: „Jeden z czołowych autorów powieści kryminalnych". Ponieważ powieść należy do podgatunku kryminału śledczego, fotografia na okładce przedstawia wejście do sądu i dwóch prawników wchodzących po schodach. Na czwartej stronie okładki znajdziemy kilka cytatów z recenzji podkreślających mistrzostwo Connelly'ego jako autora powieści kryminalnych. Obok zamieszczono także zwyczajową notę skrótowo przedstawiającą fabułę książki, sformułowaną w taki sposób, by rozbudzić ciekawość czytelnika. Kończy ją ewidentnie promocyjne hasło: „Napisana z ogromną intuicją i niezawodnym wyczuciem akcji, powieść Preokret przewyższa oczekiwania czytelników i zaspokaja apetyt na dobrze opowiedzianą historię". Jak widać, tu również nacisk położony jest na sławę autora oraz jakość książki, sytuującą ją w czołówce gatunku, bez komentarzy dotyczących społeczno-kulturowego umiejscowienia akcji.

\subsection{Wnioski z wywiadów z redaktorami i tłumaczami}

W tej sekcji przedstawiam głównie wnioski wysnute na podstawie przeprowadzonych przez siebie wywiadów. Redaktor z wydawnictwa Mozaik Knjiga poinformował mnie, że CSI nie należą do tematów szczegółowo omawianych z autorami przekładów, a zwłaszcza nie w przypadku powieści Djevojka iz susjedstva. Mirna Čubranić jest bowiem bardzo doświadczoną thumaczką, której Mozaik Knjiga regularnie zleca przekład najbardziej wymagających tekstów należących do literatury popularnej. Według redaktora teksty tego rodzaju powinny być łatwe w czytaniu i przystępne dla szerokiego odbiorcy, szczególnie dla członków „Svijet knjige” [Świata Książki], najstarszego i największego klubu książki w Chorwacji ${ }^{9}$, stanowiącego największy rynek zbytu dla wydawnictwa. Opinia tłumaczki pokrywa się ze strategią opartą na płynności lektury i przystępności tekstu. Warto odnotować, iż Čubranić - podobnie jak inni tłumacze, z którymi przeprowadziłam rozmowy - jest przekonana, że w przekładach z języka angielskiego niektóre grupy CSI mają niewielką

9 Na swojej stronie internetowej Mozaik Knjiga szczyci się, że do klubu należy ponad 30000 członków (duża liczba jak na chorwackie warunki) i definiuje misję klubu jako popularyzowanie czytelnictwa wśród różnych grup odbiorców oraz oferowanie różnorodnych pozycji. 
wagę jako odniesienia kulturowe. Wynika to z kulturowej bliskości kultury anglosaskiej i założenia, że chorwaccy czytelnicy są już oswojeni z wieloma aspektami kultury źródłowej. Natomiast przekład CSI w tłumaczeniach tekstów anglojęzycznych, lecz traktujących o kulturach bardziej odległych z punktu widzenia chorwackiego odbiorcy, wymagałby zachowania elementów nacechowanych kulturowo oraz bardziej szczegółowych objaśnień.

Zarówno redaktor, jak i tłumacz zatrudnieni przez „Profil krimić” przywiązują większą wagę do CSI. Ich zdaniem należy szukać kompromisu pomiędzy walorem informacyjnym i oczekiwaniami co do łatwości lektury przekładu. Warto odnotować, iż wśród trzech analizowanych tekstów to Privatna pacijentica zawiera największą liczbę dodatków pozatekstowych (książka zawiera aż 24 przypisy, dla porównania: w powieści Djevojka iz susjedstva zamieszczono 3, a w Preokret - 5).

Co się tyczy Lumen Izdavaštvo, główne założenie jest takie, że chorwacki przekład powinien się łatwo i przyjemnie czytać, a czytelników nie należy obarczać objaśnieniami, które nie są decydujące dla zrozumienia fabuły. Niemniej redaktor z Lumen Izdavaštvo jest zdania, iż neutralizacja bądź asymilacja elementów sygnalizujących zakorzenienie geograficzne bądź społeczno-kulturowe tekstu źródłowego jest dopuszczalna wyłącznie w przypadku, gdy ma to ułatwić czytelnikowi śledzenie fabuły. Dokładnie taka wskazówka jest zawarta w stosowanych przez wydawnictwo wytycznych dla thumaczy.

\section{Podsumowanie}

Niniejsze badanie pokazało, że elementy kulturowe związane z miejscem akcji w tekstach źródłowych są skrupulatnie zachowane w chorwackich przekładach. Jednak porównując te wnioski z danymi z wcześniejszych, diachronicznie zorientowanych badań, na początku XXI wieku można zaobserwować wyłonienie się nowych tendencji. Ściślej mówiąc, moje wcześniejsze badania (zob. Veselica-Majhut 2012) wykazały, że użycie utrwalonych w chorwackim egzotycyzmów (milja, jard, inč) przy przekładzie imperialnych jednostek miar było dominującym rozwiązaniem w latach 50., 60. i 70. Korpus zastosowany w niniejszym badaniu pokazuje, że w nowszych przekładach jednostki imperialne są nieodmiennie thumaczone na ekwiwalenty używane w kulturze docelowej (kilometar, metar, centimetar). O ile używanie ekwiwalentów z kultury docelowej nie jest nowym pomysłem, bowiem pierwsze rozwiązania tego rodzaju można zaobserwować już w tekstach z lat 70., o tyle dopiero po 
2000 roku stało się ono regularną praktyką. W porównaniu z zastąpieniem przez rozpoznawalny element egzotyzujący stosowanie ekwiwalentów z kultury docelowej jest rozwiązaniem bardziej asymilującym. Jak można ustalić na podstawie wywiadów z thumaczami i wydawcami, tendencja ta wynika prawdopodobnie z chęci ułatwienia lektury czytelnikom przekładów.

W dobranym korpusie najpopularniejszą strategią stosowaną przy odniesieniach do miejskich toponimów jest zachowanie nazwy własnej + tłumaczenie elementu językowego (np. ulica Harley). W perspektywie diachronicznej znów daje się tu zauważyć zmianę w stosunku do najczęstszej praktyki z lat 50. i 60., czyli całkowitego zachowania (Harley Street) (zob. Veselica-Majhut 2015). Choć wydaje się, ze zmiana ta wskazuje na zwrot ku bardziej asymilującym strategiom, nakierowanym na kulturę docelową, to jednak warto podkreślić, że zachowanie nazwy własnej + tłumaczenie elementu językowego pozwala zachować „obcość” miejsca akcji, jednocześnie czyniąc tekst docelowy bardziej przyjaznym dla chorwackiego czytelnika.

Można też zaobserwować inną istotną tendencję: w analizowanej próbce rozwiązania egzotyzujące, takie jak zachowanie elementu z kultury źródłowej, stosunkowo rzadko występują w parze z wewnątrztekstowymi lub pozatekstowymi dodatkami, które przekazywałyby znaczące konotacje społeczne czytelnikowi tekstu docelowego i zmniejszałyby lukę w wiedzy kulturowej istniejącą pomiędzy czytelnikami tekstu źródłowego i tekstu docelowego.

Podsumowując, zarówno dane tekstowe, jak i pozatekstowe (pozyskane dzięki analizie peritekstów oraz dzięki wywiadom) wskazują na istnienie napięć, które tłumacze muszą wyważyć, a które zdają się wynikać ze specyficznych ograniczeń związanych z przynależnością gatunkową przekładanych tekstów. Napięcia te wiążą się z potrzebą znalezienia równowagi pomiędzy łatwością lektury (i związanym z tym wynikiem sprzedażowym) oraz tekstem oferującym zniuansowany wgląd w rzeczywistość społeczną w innej kulturze, której to cesze kryminał zawdzięcza w dużej mierze swą międzynarodową popularność.

Jak wspomniano powyżej, zapewnienie płynnej lektury cenione jest wyżej niż oddanie społecznych i ideologicznych niuansów tekstu źródłowego, choć konsekwencją takiego podejścia jest zredukowanie kontekstu do mniej lub bardziej barwnego tła dla akcji. Parateksty analizowanych powieści potwierdzają powyższe wnioski: wydawcy podkreślają popularność autorów, dobrze znanych chorwackim czytelnikom, a także fabuły gwarantujące tajemnicę, napięcie i przyjemność czytania. Jak pokazują przeprowadzone wywiady, twórcy chorwackich wydań szukają kompromisu pomiędzy 
skrupulatnym oddaniem miejsca akcji w przekładzie (unikając rozwiązań o charakterze neutralizującym) a stworzeniem gładko czytającego się tekstu, pozwalającego czytelnikowi skupić się przede wszystkim na fabule, zamiast przyswajaniu informacji kulturowych.

\section{Przełożyła Aleksandra Kamińska}

\section{Bibliografia}

Aixelá J.F. 1996. Culture-Specific Items in Translation, w: R. Alvarez, C.A. Vidal (eds.), Translation, Power, Subversion, Clevedon-Philadelphia-Adelaide: Multilingual Matters, s. 62-78.

Antonini R. 2004. SAT, BLT, Spirit, Biscuits and the Third Amendment: What Italians make of Cultural References in Dubbed Texts, w: Y. Gambier, M. Schlesinger i R. Stolze (eds.), Doubts and Directions in Translation Studies, Amsterdam-Philadelphia: John Benjamins Publishing House, s. 153-168.

Davies E.E. 2003. A Goblin or a Dirty Nose? Treatment of Culture-Specific References in Translations of the Harry Potter Books, „The Translator. Studies in Intercultural Communication" 9(1), s. 65-100.

Florin S. 1993. Realia in Translation - 2014. Palimpsesty. Literatura drugiego stopnia, przeł. T. Stróżyński, A. Milecki, Gdańsk: Słowo/obraz terytoria, w: P. Zlateva (ed.), Translation as Social Action: Russian and Bulgarian Perspectives, London: Routledge, s. 122-128.

Franks R. 2011. May I Suggest Murder? An Overview of Crime Fiction for Readers' Advisory Services Staff, ,The Australian Library Journal”, 60(2), s. 133-143.

- 2014. A Taste for Murder. The Curious Case of Crime Fiction, „M/C Journal”, 17(1), http://journal.media-culture.org.au/index.php/mcjournal/article/view/770 (dostęp: 14.02.2021).

Genette G. 1997. Paratexts. Thresholds of Interpretation, przeł. J.E. Lewin, Cambridge: Cambridge University Press. - 2014. Palimpsesty. Literatura drugiego stopnia, przeł. T. Stróżyński, A. Milecki, Gdańsk: Słowo/obraz terytoria.

Gottlieb H. 2009. Subtitling against the Current. Danish Concepts, English Minds, w: J. Díaz Cintas (ed.) New Trends in Audiovisual Translation, Bristol: Multilingual Matters, s. 21-43.

Hedberg A. (2017). The Knife in the Lemon. Nordic Noir and the Glocalization of Crime Fiction, w: L. Nilsson, D. Damrosch, T. D'haen (eds.), Crime Fiction as World Literature, London-New York: Bloomsbury Academic, s. 13-22.

Hervey S., Higgins I. 1992. Thinking Translation. A Course in Translation Method: French to English, London: Routledge.

Ivir V. 1987. Procedures and Strategies for the Translation of Culture, „Indian Journal of Applied Linguistics" 13(2), s. 35-46.

Kwieciński P. 2001. Foreignisation and Domestication in Translation Procedures in the Context of Cultural Asymmetry, Torun: Edytor. 
Landers C.E. 2001. Literary Translation. A Practical Guide, Clevedon-PhiladelphiaAdelaide: Multilingual Matters.

Mailhac J.-P. 1996. The Formulation of Translation Strategies for Cultural References, w: Ch. Hoffmann (ed.), Language, Culture and Communication in Contemporary Europe, Clevedon-Philadelphia-Adelaide: Multilingual Matters, s. 132-151.

Musson J. 1999. The English Manor House. From the Archives of Country Life, London: Aurum Press.

Newmark P. 1988/1995. A Textbook of Translation, London: Prentice Hall.

Nilsson L., Damrosch D., D'haen, T. (eds.) 2017. Crime Fiction as World Literature, London-New York: Bloomsbury Academic.

Olk, H. M. 2001. The Translation of Cultural References: An Empirical Investigation into the Translation of Culture-Specific Lexis by Degree-Level Language Students, praca doktorska, Canterbury: University of Kent.

Pedersen J. 2007. Scandinavian Subtitles. A Comparative Study of Subtitling Norms in Sweden and Denmark with a Focus on Extralinguistic Cultural References, praca doktorska, Uniwersytet Sztokholmski.

Pedersen J. 2011. Subtitling Norms for Television. An Exploration Focussing on Extralinguistic Cultural References, Amsterdam-Philadelphia: John Benjamins.

Pyrhönen H. 2010. Criticism and Theory, w: Ch.J. Rzepka, L. Horsley (eds.), A Companion to Crime Fiction, Chichester: John Wiley and Sons, s. 43-56.

Rolls A. 2015. The Re-imagining Inherent in Crime Fiction Translation, „M/C Journal" 18 (6), https://journal.media-culture.org.au/index.php/mcjournal/article/ view/1028 (dostęp: 12.02.2021).

Rolls A., Vuaille-Barcan M.L., West-Sooby J. 2016. Translating National Allegories. The Case of Crime Fiction, „The Translator” 22(2), s. 135-143.

Scott-Brown S. 2017. The Histories of Raphael Samuel. A Portrait of a People's Historian, Acton: ANU Press.

Seago K. (2014). Introduction and Overview. Crime (fiction) in Translation, „The Journal of Specialised Translation" (22), s. 2-14.

Toury G. 1995. Descriptive Translation Studies and Beyond, Amsterdam-Philadelphia: John Benjamins. - 2009, Metoda opisowych badań przekładu, przeł. A. Sadza, w: P. Bukowski, M. Heydel (red.), Współczesne teorie przekładu, Kraków: Znak.

Veselica-Majhut S. Cultural Specificity in the Translation of Popular Fiction from English into Croatian during the Socialist and Transition Periods (1960-2010). Praca doktorska. Universitat Rovira i Virgili.

Veselica Majhut S., Bašić I. 2015. From Foot to Meter: Rendering of Culture-specific Items in Popular Fiction Translations from English to Croatian, w: A. Peti-Stantic, M. Milan Stanojevic i G. Antunovic (eds.), Language Varieties between Norms and Attitudes, Peter Lang: Frankfurt am Main, Berlin, Bern, Bruxelles, New York, Oxford, Wien, s. 197-217.

Westin I. 2002. Language Change in English Newspaper Editorials, Amsterdam-New York: Rodopi.

Worthington H. 2011. Key Concepts in Crime Fiction, Basingstoke: Palgrave Macmillan. 